\title{
MHC-independent genetic regulation of liver damage in a mouse model of autoimmune hepatocellular injury
}

\author{
Jack T Lin ${ }^{1}$, Tamar J Kitzmiller ${ }^{1,2}$, Justin MM Cates ${ }^{2}$ and James D Gorham ${ }^{1,2,3}$ \\ ${ }^{1}$ Department of Microbiology and Immunology, The Norris Cotton Cancer Center, Dartmouth Medical School, \\ Lebanon, NH, USA; ${ }^{2}$ Department of Pathology, The Norris Cotton Cancer Center, Dartmouth Medical School, \\ Lebanon, NH, USA and ${ }^{3}$ The Norris Cotton Cancer Center, Dartmouth Medical School, Lebanon, NH, USA
}

\begin{abstract}
Autoimmune hepatitis (AIH) is mediated by a T-cell attack upon liver parenchyma. Susceptibility to the development of AlH is genetically determined. While particular MHC haplotypes are known risk factors, it has been widely speculated that autoimmune liver damage can be regulated by additional genetic loci unlinked to MHC. However, evidence for the existence of such loci in humans is scant. We examined the contribution of the MHC in a murine model of autoimmune hepatocellular injury. BALB/C mice lacking the immunoregulatory cytokine transforming growth factor-beta1 (TGF-ק1) rapidly develop autoimmune T-helper 1-mediated necroinflammatory liver disease. Susceptibility to liver damage is strictly regulated by genetic background. Whereas TGF- $\beta 1$-deficient mice on the BALB/c background develop necroinflammatory liver disease, TGF- $\beta 1$ deficient mice on the 129/CF-1 genetic background do not. We asked whether MHC locus haplotype is the principal determinant of genetic susceptibility to liver disease in this model system. BALB/c mice harbor the H$2^{\mathrm{d}}$ haplotype. We used a 'haplotype swapping' approach to generate $\mathrm{H}-2^{\mathrm{b}}$ or $\mathrm{H}-2^{\mathrm{k}}$ congenic BALB-background TGF- $\beta 1$-deficient mice. In addition, F1 (BALB/c $\times$ 129/CF-1)-TGF- $\beta 1$-deficient mice were generated. As determined by plasma transaminase levels and histopathology, severe necroinflammatory liver disease developed in all BALB-background TGF- $\beta 1$-deficient mice, regardless of $\mathrm{H}-2$ haplotype, but developed neither in

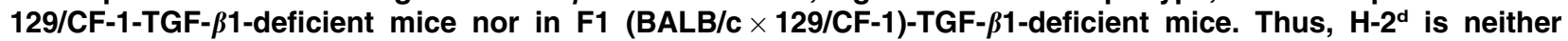
necessary nor sufficient for the development of necroinflammatory liver disease in BALB-background TGF- $\beta 1$ deficient mice. This constitutes the first direct evidence that susceptibility to autoimmune hepatocellular damage, at least in mice, can be determined by genetic loci distinct from the MHC.
\end{abstract}

Laboratory Investigation (2005) 85, 550-561, advance online publication, 31 January 2005; doi:10.1038/labinvest.3700246

Keywords: autoimmunity; TGF- $\beta 1$; hepatocellular injury; genetics; murine

The human disease autoimmune hepatitis (AIH) is caused by an unremitting immune attack upon hepatocytes that leads to widespread liver destruction and organ failure. ${ }^{1}$ While the underlying etiology of AIH remains mysterious, the disease is associated with the presence in liver of numerous $\mathrm{CD}^{+} \mathrm{T}$ cells expressing high levels of the Th1 cytokines interferon (IFN)- $\gamma$ and tumor necrosis factor (TNF)- $\alpha^{2,3}$ It is well accepted that genetic susceptibility plays a significant role in the pathogenesis of AIH. Early studies demonstrated that major histocompatibility complex (MHC) haplotype

Correspondence: Dr JD Gorham, MD, PhD, Department of Pathology, Dartmouth Medical School, One Medical Center Drive, Lebanon, NH 03756, USA.

E-mail: James.D.Gorham@Dartmouth.edu

Received 18 June 2004; revised 17 December 2004; accepted 19 December 2004; published online 31 January 2005 influences disease susceptibility ${ }^{4-6}$ and other studies have confirmed that the MHC haplotype A1-B8DR3 is an important risk factor for the development of AIH in Northern European populations. ${ }^{7,8}$ The MHC human leukocyte antigen (HLA) DR4 allele appears to be an additional independent risk factor. $^{8-10}$ Since the MHC locus is critically involved in molding and regulating the T-cell repertoire, its prominent involvement is consistent with the autoimmune nature of the disease and the concept that autoreactive $\mathrm{T}$ helper 1 (Th1) cells mediate disease pathogenesis. However, most individuals harboring A1-B8-DR3 or DR4 do not develop AIH; conversely not all AIH patients carry these particular MHC haplotypes. ${ }^{11}$

It has been hypothesized therefore that additional non-MHC loci may regulate the onset or progression of immune-mediated liver damage in AIH. ${ }^{12,13}$ Evidence supporting this hypothesis has been 
difficult to obtain principally because of the low prevalence of disease. The principal investigative strategy for identifying AIH susceptibility loci unlinked to MHC is the 'candidate' gene approach involving population-based case-control studies. In this approach, a hypothesis is made regarding the involvement of a gene in the pathogenesis of disease, and investigators then assess the relative frequencies in patient and control populations of allelic polymorphisms of the gene in question. Using this approach, Agarwal et $a l^{14}$ demonstrated that a particular polymorphism (the presence of $G$ instead of A) at position 49 in exon 1 of the gene encoding the T-cell inhibitory molecule CTLA-4 (located on chromosome 2q33) is found at higher frequency in AIH patients (68\%) than in normal subjects $(50 \%)$. Similar candidate gene approaches have failed to show association of AIH with polymorphisms in genes encoding the cytokines interleukin (IL) -1 or IL-10, or the IL-1 receptor antagonist. ${ }^{15,16}$

Mouse models have been informative in elucidating the genetic bases of the onset, progression, and regulation of organ-specific autoimmune diseases. For example, genetic analyses of nonobese diabetic (NOD) mice, a model for type I diabetes mellitus, have demonstrated the importance of the MHC locus in regulating autoimmune attack upon insulinproducing islet beta cells. Early studies demonstrated that the NOD background MHC class II allele $\mathrm{I}-\mathrm{A}^{\mathrm{g} 7}$ is essential for the development of autoimmune diabetes, as NOD congenic mice in which the $\mathrm{I}-\mathrm{A}^{\mathrm{g} 7}$ allele has been substituted with the I-A ${ }^{\mathrm{b}}$ allele fail to develop diabetes. ${ }^{17}$ Extensive genetic analyses of a variety of murine autoimmune disease models have demonstrated that both MHC and non-MHC loci contribute to disease susceptibility. ${ }^{18-20}$

In low prevalence multifactorial polygenic diseases, the analysis of genetic susceptibility loci can be greatly facilitated through the use of robust animal model systems. We have recently developed a mouse model of autoimmune hepatocellular injury that shares certain key features with the human disease AIH. BALB/C mice deficient in the immunoregulatory cytokine transforming growth factorbeta1 (TGF- $\beta 1$ ) uniformly and predictably develop early-onset aggressive necroinflammatory liver disease before 2 weeks of age. ${ }^{21}$ Histologically, hepatic injury is characterized by confluent hepatocellular necrosis associated with a mixed inflammatory infiltrate. Increased numbers of $\mathrm{CD}^{+} \mathrm{T}$ cells are also detectable in diseased livers by flow cytometry. ${ }^{22}$ Hepatic CD4 ${ }^{+}$T cells from BALB/C-TGF- $\beta 1^{-1-}$ mice express high levels of the Th1 cytokine IFN- $\gamma$. Necroinflammatory liver disease in BALB/c-TGF$\beta 1^{-1-}$ mice is prevented if mice are rendered deficient either in $\mathrm{CD}^{+}{ }^{+} \mathrm{T}$ cells (through in vivo depletion of $\mathrm{CD} 4^{+} \mathrm{T}$ cells, using a subset-specific monoclonal antibody ${ }^{22}$ ), or in IFN- $\gamma$ (through the development of BALB/C-TGF- $\beta 1^{-/-} / \mathrm{IFN}-\gamma^{-/-}$double knockout mice ${ }^{21}$ ), confirming the Th1 pathogenesis of liver damage. Importantly, disease is strictly dependent upon genetic background. TGF- $\beta 1^{-1-}$ mice on the BALB/c background rapidly develop necroinflammatory liver disease, whereas TGF- $\beta 1^{-\prime-}$ mice on another background (129/CF-1) do not develop necroinflammatory liver disease. ${ }^{21}$ This indicates the presence of a genetic locus or loci with background-specific alleles that exert influence in modifying the development and/or progression of necroinflammatory liver disease in TGF- $\beta 1$-deficient mice.

The TGF- $\beta 1^{-1-}$ mouse model exhibits a powerful influence of genetic background on autoimmune liver disease. BALB/c mice are inbred and all carry a specific MHC haplotype (d) at $\mathrm{H}-2$, the murine MHC locus. We therefore hypothesized that the BALB/Cspecific $\mathrm{H}-2^{\mathrm{d}}$ haplotype is essential for the development of organ-specific necroinflammatory liver disease in this murine model of autoimmune hepatocellular injury. We have rigorously tested that hypothesis here, via a genetic 'haplotype-swapping' approach using available $\mathrm{H}-2$ congenic strains extensively backcrossed to the BALB background.

\section{Materials and methods}

\section{Mouse Breeding and H-2 Haplotypes}

Mice were bred in the Dartmouth Medical School animal care facility, and treated humanely, according to National Institutes of Health (NIH) guidelines. JDG has an approved Dartmouth Medical School IACUC protocol for these studies. For all breeder mice, TGF- $\beta 1$ genotype was determined by polymerase chain reaction (PCR) using DNA purified from tail snips and confirmed independently by a repeat PCR using DNA from a separate tail snip.

$B A L B / C-T G F-\beta 1^{+/-}$breeders

The derivation of $\mathrm{H}-2^{\mathrm{d} / \mathrm{d}}$ BALB/C(N6)-TGF- $\beta 1^{+/-}$ breeders has been described. ${ }^{21}$

\section{$129 / C F-1-T G F-\beta 1^{+/-}$breeders}

$129 / \mathrm{CF}-1$-TGF- $\beta 1^{+/-}$mice were originally obtained from Tom Doetschman (U. Cincinnati). ${ }^{21,23} 129 /$ Sv1TGF- $\beta 1^{+/-}$mice were derived from founder mice of the original targeted deletion of the TGF- $\beta 1$ gene in $129 /$ Sv1 ES cells. 129/Sv1-TGF- $\beta 1^{+/-}$mice were subsequently bred with CF-1 mice, an outbred strain available from Charles River Laboratories. 129/CF-1TGF- $\beta 1^{-1-}$ mice were maintained using the 'advanced intercross line' ${ }^{24}$ genetic breeding technique that serves to maximize genetic heterogeneity in a population of animals. The H-2 haplotype of the inbred 129/Sv1 mouse strain is defined as H-2 ${ }^{\text {bc }}$, a closely related variant of the $\mathrm{H}-2^{\mathrm{b}}$ haplotype ${ }^{25}$ The $\mathrm{H}-2^{\text {bc }}$ haplotype for 129 mice was proposed by Snell in 1971, following the demonstration of clear H-2linked resistance to skin grafts with $\mathrm{H}^{2}{ }^{\mathrm{b}}$ from C57BL $/ 10{ }^{26}$ Subsequent molecular analysis revealed clear differences from C57BL/6 in the H2-T 
region encoding the non-classical class I gene Tla. ${ }^{27}$ The H-2 haplotype of the outbred CF-1 strain appears to be $\mathrm{H}-2^{\mathrm{k}}$. The initially inbred CF-1 strain has been maintained as an outbred strain (permitting genetic drift) for at least the past 30 years (see http://www.criver.com/products/research_models/ documents/Research_Models_2004_catalog_Outbred_ Mice.pdf). In approximately 1994, the H-2 haplotypes of about $100 \mathrm{CF}-1$ mice were extensively tested at Charles River Laboratories, and all were found to harbor only the $\mathrm{H}-2^{\mathrm{k}}$ haplotype (Patricia A Mirley, Charles River Laboratories, personal communication). New H-2 haplotypes may have emerged subsequently in this unmonitored population, through the acquisition of new (ie nontypeable) mutations, but the probability of this is low, as the mutation rate of $\mathrm{H} 2$ class I and class II loci has been shown to be no higher, and probably significantly lower than, $1.7 \times 10^{-4}$ per gene per generation. ${ }^{28}$ Genomes of the genetically heterogeneous $129 / \mathrm{CF}-1-\mathrm{TGF}-\beta 1^{+/-}$mice are blends of the inbred 129/Sv1 and outbred CF-1 backgrounds. We anticipated therefore that the $\mathrm{H}-2$ haplotypes of these mice to be some combination of $\mathrm{H}-2^{\mathrm{b}}, \mathrm{H}-2^{\mathrm{k}}$, and possibly some nontypeable $\mathrm{H}-2$ haplotypes. Testing the $\mathrm{H}-2$ haplotypes of four male and four female 129/CF-1-TGF- $\beta 1^{+/-}$breeder mice in our colony yielded the results $\mathrm{H}-2^{\mathrm{b}+\mathrm{d}-\mathrm{k}-}$ for all eight mice (TJK, unpublished), making it likely that $\mathrm{H}-2^{\mathrm{bc}}$ is the predominant, and perhaps the only, $\mathrm{H}-2$ haplotype present in this population. However, the presence of non-typeable $\mathrm{H}-2$ haplotypes cannot be definitively ruled out without more extensive testing.

\section{H-2 congenic BALB-TGF- $\beta 1^{+/-}$breeders}

BALB.B $\left(\mathrm{H}-2^{\mathrm{b} / \mathrm{b}}\right)$ mice and BALB.K. $\left(\mathrm{H}-2^{\mathrm{k} / \mathrm{k}}\right)$ mice were purchased from Jackson Laboratories. $\mathrm{H}-2^{\mathrm{d} / \mathrm{d}}$ $\mathrm{BALB} / \mathrm{C}(\mathrm{N} 6)-\mathrm{TGF}-\beta 1^{+/-}$breeders were crossed with BALB.B mice using both female-male and malefemale crosses. All first-generation mice were $\mathrm{H}-2^{\mathrm{b} / \mathrm{d}}$, and approximately $50 \%$ were TGF- $\beta 1^{+/-}$. TGF- $\beta 1^{+/-}$ mice were identified by PCR and selected for a second backcross with BALB.B mice. At the second generation, approximately $25 \%$ of mice were both $\mathrm{H}-2^{\mathrm{b} / \mathrm{b}}$ and TGF- $\beta 1^{+/-}$. Males and females that typed as $\mathrm{H}-2^{\mathrm{b} / \mathrm{b}}$-TGF- $\beta 1^{+/-}$were interbred to generate $(\mathrm{H}-$ $2^{\mathrm{b} / \mathrm{b}}$ ) BALB.B-TGF- $\beta 1^{-1-}$ mice, and littermate control mice. The generation of $\left(\mathrm{H}-2^{\mathrm{k} / \mathrm{k}}\right)$ BALB.K-TGF- $\beta 1^{-1-}$ mice followed a parallel strategy.

\section{F1-TGF- $\beta 1^{-/-}$pups}

BALB/C-TGF- $\beta 1^{+/-}$mice were bred with $129 / \mathrm{CF}-1$ TGF- $\beta 1^{-1-}$ mice to generate F1 pups. Both male (BALB)-female (129/CF-1) and female (BALB)male (129/CF-1) strategies were used.

\section{TGF-ק1 Genotyping}

Cages were monitored daily for the birth of new litters, defined as day 0 . At 3-5 days of age, pups were permanently marked on the tail using a tattoo kit, and genotyping was done on tail snips from these pups, by PCR using the following primer combination: 5'-TTGCTGTACTGTGTGTCCAG-3', 5'-CAGGACATAGCGTTGGCTAC-3' ${ }^{\prime}, 5^{\prime}$-TCCACAGA GAAGAACTGCTG- ${ }^{\prime}$. This single PCR distinguishes the wild-type, heterozygous, and knockout genotypes. When mice were analyzed at day 11 , a repeat tail snip was taken and another PCR was performed to confirm TGF- $\beta 1$ genotype.

\section{H-2 Haplotyping}

RBC-lysed peripheral blood mononuclear cells from potential founder BALB-TGF- $\beta 1^{+/-} \mathrm{H}-2$ congenic breeder mice were stained with the following typing reagents: FITC-anti-H-2D ${ }^{\mathrm{d}}$ (PharMingen) with either

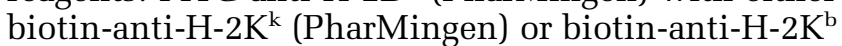
(PharMingen), as appropriate. Biotinylated antibodies were detected with streptavidin-phycoerythrin. Samples were analyzed by flow cytometry. All breeder mice were tested for $\mathrm{H}-2$ haplotype at least twice.

\section{Aspartate Aminotransferase (AST) and Alanine Aminotransferase (ALT) Analyses}

Deeply anesthetized 11-12-day-old pups were decapitated and pooling cervical blood was collected using heparinized capillary tubes. Plasma was recovered from centrifugation of blood in BectonDickinson Vacutainer plasma separator tubes. AST and ALT activity levels in plasma were determined within one hour of collection using a Roche-Hitachi 917 Automatic Analyzer, employing an ultraviolet (UV) kinetic enzymatic assay read at $340 \mathrm{~nm}$.

\section{Histology}

After anesthesia and euthanasia of mice, organs (liver, heart, intestine, kidneys, brain) were dissected out and fixed in buffered formalin, followed by paraffin embedding, sectioning, and staining with hematoxylin and eosin (H\&E), by routine methods.

\section{Statistical Analyses}

Data for plasma enzyme levels were analyzed using Student's unpaired two-tailed $t$-test, with significance accepted at $P<0.05$.

\section{Results}

We hypothesized that the BALB/c MHC haplotype, $\mathrm{H}-2^{\mathrm{d}}$, is necessary for necroinflammatory liver disease in BALB/c-TGF- $\beta 1^{-1-}$ mice. To directly test this hypothesis, we took advantage of the availability of existing H-2 congenic strains extensively 
back-bred to the BALB-background. BALB.B mice are homozygous for the $\mathrm{H}-2^{\mathrm{b}}$ haplotype at the MHC, but are otherwise syngeneic with BALB/C at genetic loci unlinked to the MHC. Similarly, BALB.K mice are homozygous for the $\mathrm{H}-2^{\mathrm{k}}$ haplotype, but are otherwise syngeneic with $\mathrm{BALB} / \mathrm{c}$ at loci unlinked to MHC. To develop $\mathrm{H}-2^{\mathrm{b} / \mathrm{b}}$ congenic BALB-background TGF- $\beta 1^{-/-}$mice, BALB/c-TGF- $\beta 1^{+/-}$(N6 backcross; $\left.\mathrm{H}-2^{\mathrm{d} / \mathrm{d}}\right)$ mice $^{21}$ were bred with BALB.B mice to generate BALB.B-TGF- $\beta 1^{+/-}$breeder mice. PCR was used to select for TGF- $\beta 1^{+/-}$mice, and haplotype-specific cell surface markers and flow cytometry were used to select for $\mathrm{H}-2^{\mathrm{b} / \mathrm{b}}$ mice. Male and female $\mathrm{H}-2^{\mathrm{b} / \mathrm{b}}$ BALB.B-TGF- $\beta 1^{+/-}$breeder mice were then intercrossed to generate BALB.B-TGF$\beta 1^{-1-}$ mice as well as littermate control BALB.BTGF- $\beta 1^{+/-}$mice and BALB.B-TGF- $\beta 1^{+/+}$mice. Pups were screened by PCR for TGF- $\beta 1$ genotype at 3-5 days of age. A parallel strategy was used to generate BALB.K-TGF- $\beta 1^{-l-}$ mice and littermate control mice.

We assessed embryonic viability of TGF- $\beta 1^{-/-}$ conceptuses. Some TGF- $\beta 1^{-1-}$ embryos die early in development, through a mechanism involving improper development of the yolk sac vasculature. ${ }^{29}$ This phenotype is partially penetrant, and penetrance is dependent upon genetic background. ${ }^{21,30}$ On the BALB/c background, embryonic lethality was observed for some TGF- $\beta 1^{-1-}$ conceptuses, as we have previously published. ${ }^{21} \mathrm{BALB} / \mathrm{c}-\mathrm{TGF}-\beta 1^{-/-}$, BALB.B-TGF- $\beta 1^{-1-}$, and BALB.K-TGF- $\beta 1^{-1-}$ conceptuses all exhibited similar rates of developmental viability $(\sim 20 \%)$ (Table 1$)$, indicating that $\mathrm{H}-2$ haplotype is not a determinant of the penetrance of this phenotype.

BALB/c-TGF- $\beta 1^{-/-}$mice spontaneously develop $\mathrm{CD}^{+}{ }^{+}$-T-cell-dependent necroinflammatory liver disease, beginning between postnatal days 7 and $10 .^{22}$ In contrast, 129/CF-1-TGF- $\beta 1^{-/-}$mice do not develop necroinflammatory liver disease, but succumb to $\mathrm{CD}^{+}{ }^{+}$-T-cell-dependent autoimmune pathologies involving other organs. ${ }^{31,32}$ To determine whether the $\mathrm{H}-2^{\mathrm{d}}$ haplotype is necessary for the development of necroinflammatory liver disease in BALB-background TGF- $\beta 1^{-1-}$ mice, TGF- $\beta 1^{-1-}$ mice (and littermate controls) from the various backgrounds were euthanized at day 11-12. Plasma samples were collected for transaminase analyses (Figure 1), and livers were dissected out for histologic analyses (Figures 2 and 3). In 129/CF-1TGF- $\beta 1^{-\prime-}$ mice, plasma AST and ALT levels were not elevated compared with littermate TGF- $\beta 1^{+/+}$ mice, and were only slightly elevated compared with littermate TGF- $\beta 1^{+/-}$mice (Figure 1; Table 2). In BALB/c-TGF- $\beta 1^{-1-}$ mice, by contrast, plasma AST and ALT levels were greatly elevated, compared either with littermate control mice or with 129/CF-1TGF- $\beta 1^{-1-}$ mice. These data are consistent with our previously published results. ${ }^{21}$ For the BALB H-2 congenic TGF- $\beta 1^{-1-}$ mice, results were not distinguishable from those observed for BALB/C-TGF- $\beta 1^{-1-}$ mice. That is, plasma AST and ALT levels were greatly elevated in BALB.B-TGF- $\beta 1^{-1-}$ mice and in BALB.K-TGF- $\beta 1^{-1-}$ mice, compared with their respective littermate control mice. Furthermore, plasma AST and ALT levels in BALB.B-TGF- $\beta 1^{-/-}$mice and in BALB.K-TGF- $\beta 1^{-1-}$ mice were not statistically different from those observed for BALB/C-TGF$\beta 1^{-I-}$ mice, but were highly statistically different from those observed for $129 / \mathrm{CF}-1-\mathrm{TGF}-\beta 1^{-1-}$ mice.

We inspected livers at the macroscopic and microscopic levels. Grossly, regardless of $\mathrm{H}-2$ haplotype, all BALB-background (BALB/c, BALB.B, BALB.K) TGF- $\beta 1^{-1-}$ livers had similar lesions, consisting of mottled patchy discoloration of all lobes that probably reflects areas of hemorrhagic necrosis (data not shown). By contrast, 129/CF-1TGF- $\beta 1^{-/-}$livers were grossly normal, and indistinguishable from littermate control livers.

Histologic analyses of livers from BALB/C-TGF$\beta 1^{-1-}$ mice showed necroinflammatory liver disease, but the histologic features were distinct from those

Table 1 Genotype data of pups from TGF- $\beta 1^{+/-}$intercrosses

\begin{tabular}{|c|c|c|c|c|c|}
\hline \multirow[t]{2}{*}{ Genetic background } & \multicolumn{3}{|c|}{ TGF- $\beta 1$ genotypes of pups $s^{\mathrm{a}}$} & \multirow[t]{2}{*}{ Total } & \multirow[t]{2}{*}{ Ratio $(-/-:+/+)^{\mathrm{b}}$} \\
\hline & $-1-$ & $+/-$ & $+/+$ & & \\
\hline $\mathrm{BALB} / \mathrm{c}$ & 22 & 201 & 109 & 332 & 0.20 \\
\hline BALB.B & 10 & 104 & 46 & 160 & 0.22 \\
\hline BALB.K & 11 & 120 & 71 & 202 & 0.16 \\
\hline 129/CF-1 & 37 & 69 & 37 & 143 & 1.00 \\
\hline $\mathrm{F} 1^{\mathrm{c}}$ & 12 & 31 & 11 & 54 & 1.09 \\
\hline
\end{tabular}

\footnotetext{
${ }^{\mathrm{a}}$ Pups were screened at $3-5$ days of age by PCR for TGF- $\beta 1$ from tail-snip DNA as in Materials and methods. The numbers of pups for each TGF- $\beta 1$ genotype generated for this study are indicated.

${ }^{\mathrm{b}}$ The number indicates the ratio of TGF- $\beta 1^{-/-}$pups to TGF- $\beta 1^{+/+}$pups. A $\left(-/-t_{+} /+\right)$ratio of 1 is expected for Mendelian inheritance. For BALBbackground groups, this ratio is lower than 1, indicating embryonic lethality of most TGF- $\beta 1^{-/-}$conceptuses. While genetic background influences the rate of embryonic loss of TGF- $\beta 1^{-l-}$ conceptuses (Gorham et al ${ }^{21}$ and Kallapur $e t a l^{30}$ and data in Table 1), H-2 haplotype is not a genetic determinant of embryonic lethality of BALB-background TGF- $\beta 1^{-/-}$conceptuses.

${ }^{\mathrm{C}} \mathrm{F} 1$ pups were generated from BALB/C-TGF- $\beta 1^{+/-}$mice crossed with $129 / \mathrm{CF}-1-\mathrm{TGF}-\beta 1^{+/-}$mice. The $(-/-:+/+)$ratio is $\sim 1$, indicating that the BALB-background phenotype of a $(-/-:+/+)$ ratio of $\sim 0.2$ is recessively inherited in this cross.
} 

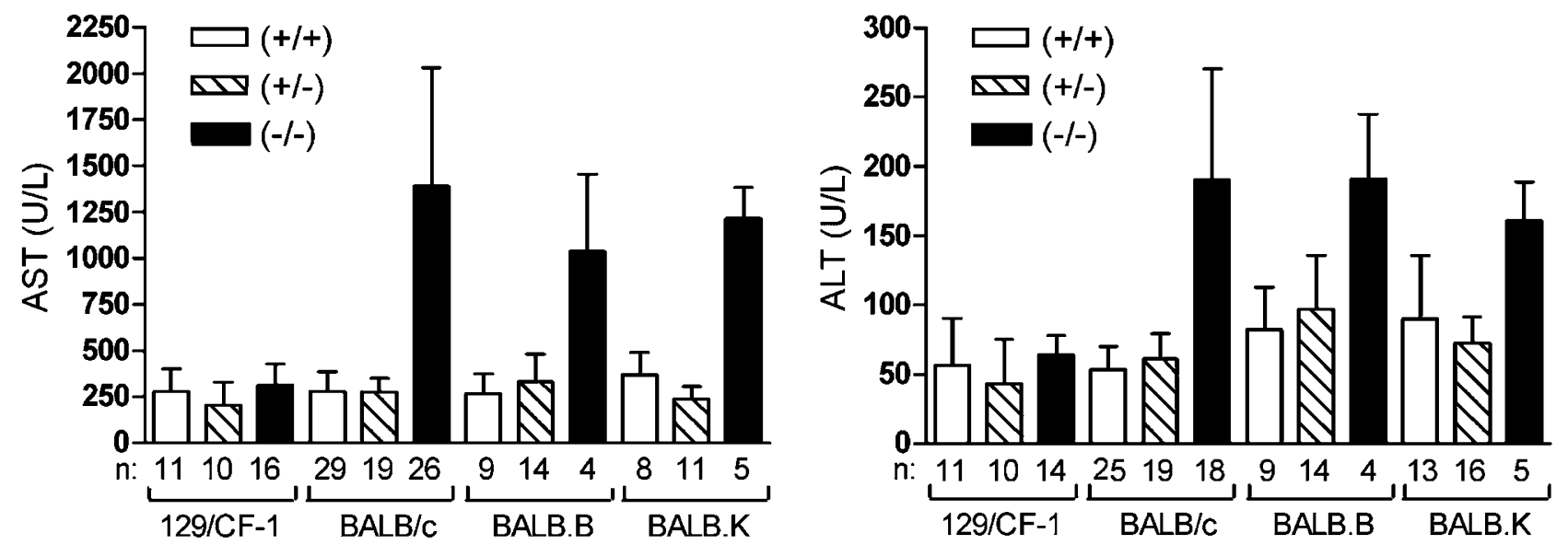

Figure 1 Elevation of transaminase levels in BALB-background TGF- $\beta 1^{-/-}$mice does not require the H-2 ${ }^{\mathrm{d}}$ haplotype. Litters from TGF$\beta 1^{+/-}$intercrosses on the genetic backgrounds shown were killed at postnatal day 11-12 and plasma samples were collected for AST and ALT analyses. Bars show means + standard deviation (SD) for TGF- $\beta 1$ wild-type $(+/+)$ heterozygous $(+/-)$ and knockout $(-/-)$ mice, respectively, within each genetic background. The numbers $(n)$ of mice analyzed in each group are shown below the bars. Corresponding statistical analyses are shown in Table 2.

of human AIH. In humans, AIH is characterized by a mixed inflammatory infiltrate, predominantly composed of lymphocytes and plasma cells, interface hepatitis, and variable degrees of hepatocellular necrosis and portal fibrosis. As compared with control livers (Figure 2a), BALB/C-TGF- $\beta 1^{-1-}$ livers showed confluent hepatocellular necrosis, predominantly in a subcapsular distribution (Figure 2b). There was no associated peritoneal inflammation (not shown). Centrilobular necrosis could also be seen in deeper liver parenchyma, away from the hepatic capsule (Figure 2c). High-power examination revealed an associated mixed inflammatory infiltrate, with polymorphonuclear cells a prominent feature (Figure 2d). Notably, plasma cells were absent, and significant portal inflammation, interface hepatitis, and fibrosis were not commonly seen (Figure 2e), features that distinguish this pathology from that typically observed in human AIH.

We examined the histology of livers from TGF$\beta 1^{-1-}$ mice on the other backgrounds. Livers from $129 / \mathrm{CF}-1-\mathrm{TGF}-\beta 1^{-\prime-}$ mice were normal and lacked the distinct widespread hepatocellular necrosis observed in BALB/c-TGF- $\beta 1^{-/-}$mice (Figure 3a). In the H-2 congenic BALB-TGF- $\beta 1^{-1-}$ livers, histopathology was similar to that observed in BALB/CTGF- $\beta 1^{-I-}$ livers. That is, confluent subcapsular and centrilobular hepatocellular necrosis with an associated mixed inflammatory infiltrate dominated by neutrophils was observed in livers from both BALB.B-TGF- $\beta 1^{-/-}$mice (Figure $3 \mathrm{~b}$ ) and BALB.KTGF- $\beta 1^{-/-}$mice (Figure 3c). Extramedullary hematopoiesis (EMH), most prominently seen within and adjacent to portal tracts, was a common feature of livers from all mice at age 11-12, but there was no difference in the extent or pattern of EMH between any of the groups studied.

In additional studies, we bred BALB/c-TGF- $\beta 1^{+/-}$ mice with $129 / \mathrm{CF}-1$-TGF- $\beta 1^{+/-}$mice to generate
F1-TGF- $\beta 1^{-l-}$ mice, as well as control littermate F1-TGF- $\beta 1^{+/-}$mice and F1-TGF- $\beta 1^{+/+}$mice. Livers from 11-day-old F1-TGF- $\beta 1^{-1-}$ mice were normal upon gross inspection (data not shown), similar to livers from $129 / \mathrm{CF}-1-\mathrm{TGF}-\beta 1^{-1-}$ mice. Analyses of AST and ALT showed no elevation in F1-TGF- $\beta 1^{-/-}$ plasma compared with littermate control plasma (Figure 4, Table 3). F1-TGF- $\beta 1^{-1-}$ plasma AST and ALT levels were significantly different from those measured from BALB/c-TGF- $\beta 1^{-1-}$ plasma. F1-TGF$\beta 1^{-1-}$ plasma AST levels were not different from those measured from 129/CF-1-TGF- $\beta 1^{-1-}$ plasma. While F1-TGF- $\beta 1^{-1-}$ plasma ALT levels were somewhat elevated compared with 129/CF-1-TGF- $\beta 1^{-/-}$ plasma ALT levels, this appears to be due more to an effect of an overall increased level of ALT in F1-background plasma in general (see data for F1 littermate controls; Figure 4), than to an effect specific to the absence of TGF- $\beta 1$. Moreover, histologic analyses of eleven F1-TGF- $\beta 1^{-/-}$livers showed no evidence of the hepatocellular necrosis and acute inflammation characteristic of BALBbackground TGF- $\beta 1^{-1-}$ livers (Figure $3 \mathrm{~d}$ ). Taken together, these results show that the BALB/c-background susceptibility to necroinflammatory liver disease in TGF- $\beta 1^{-\prime-}$ mice is recessively inherited in this F1 cross. Importantly, since F1 mice inherit a single $\mathrm{H}-2^{\mathrm{d}}$ haplotype from the BALB/c parent, these data also show that harboring the $\mathrm{H}-2^{\mathrm{d}}$ haplotype is not sufficient for liver disease susceptibility in TGF$\beta 1^{-/-}$mice.

The finding of subcapsular necrotic changes in BALB-background TGF- $\beta 1^{-1-}$ livers suggested the possibility that the etiology of liver disease in these mice might be secondary to systemic ischemia due to hypoperfusion. For this reason, we assessed the histology of hearts from BALB/C-TGF- $\beta 1^{+/+}$control mice (Figure 5a) and BALB/c-TGF- $\beta 1^{-1-}$ mice (Figure 5b); BALB/c-TGF- $\beta 1^{-/-}$hearts showed 

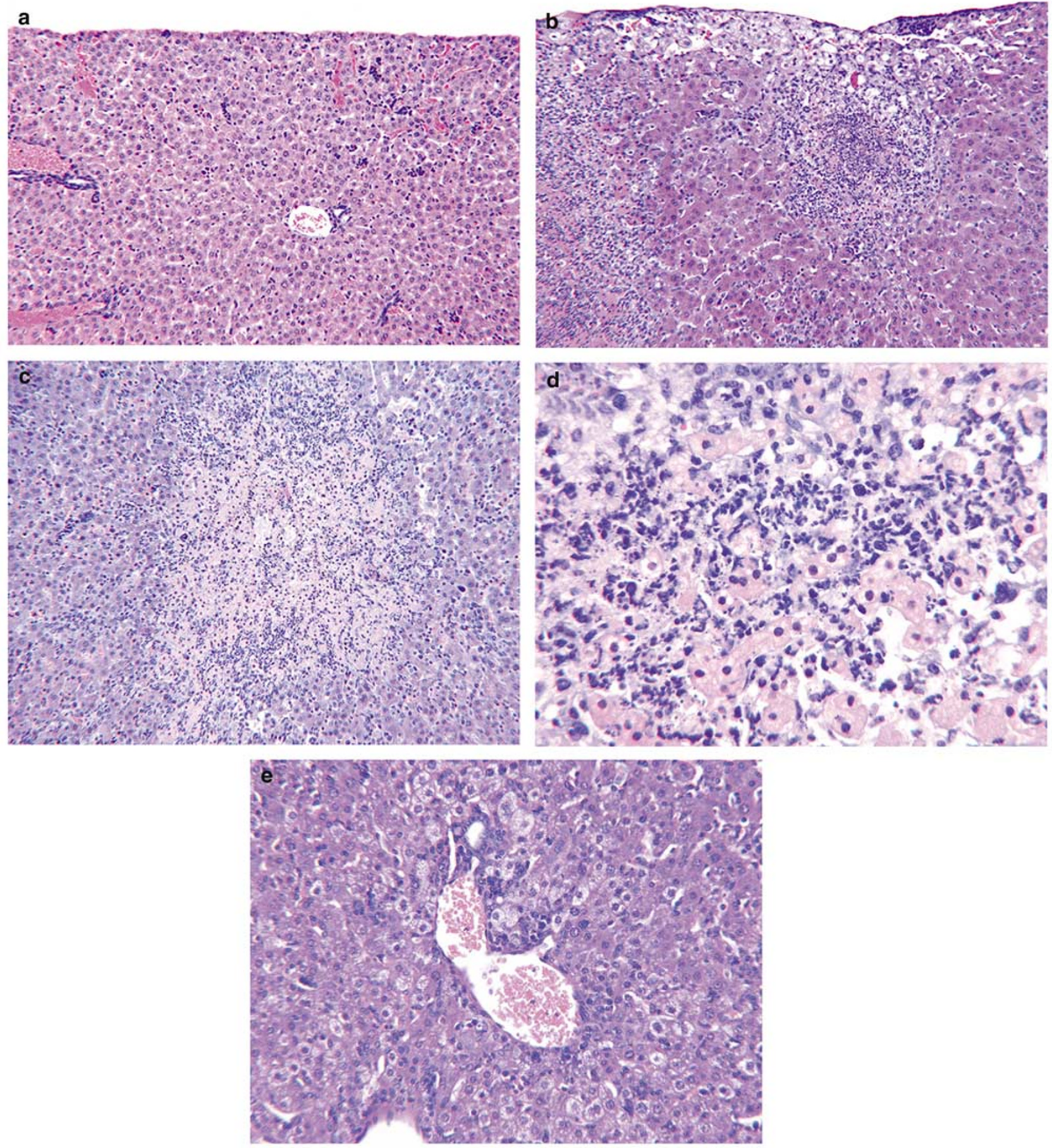

Figure 2 Necroinflammatory changes in BALB/C-TGF- $\beta 1^{-/-}$livers (H\&E-stained sections). (a) Normal histology in BALB/c-TGF- $\beta 1^{+/+}$ liver; (b) BALB/c-TGF- $\beta 1^{-1-}$ livers show extensive necroinflammatory liver disease, primarily in a subcapsular distribution; (c) similar findings are also observed in deeper hepatic parenchyma from BALB/c-TGF- $\beta 1^{-1-}$ mice; (d) high-power examination of the inflammatory infiltrate seen in necrotic areas from BALB/c-TGF- $\beta 1^{-l-}$ mice shows a predominance of neutrophils admixed with histiocytes and lymphocytes. Notably, no plasma cells are seen; (e) portal triads in BALB/c-TGF- $\beta 1^{-1-}$ livers show a lack of inflammation, interface hepatitis, and fibrosis.

moderate to severe lymphocytic infiltration of the myocardium, sometimes associated with myocyte damage, reminiscent of autoimmune-mediated myocarditis. In contrast, hearts from 129/CF-1-TGF- $\beta 1^{-1-}$ mice of this age were relatively free of lymphocytic infiltration (Figure 5c). Although the presence of myocardial inflammation may suggest a possible ischemic etiology for the hepatocellular damage observed in BALB/c-TGF- $\beta 1^{-/-}$mice, no other histopathological signs of systemic hypoperfusion 


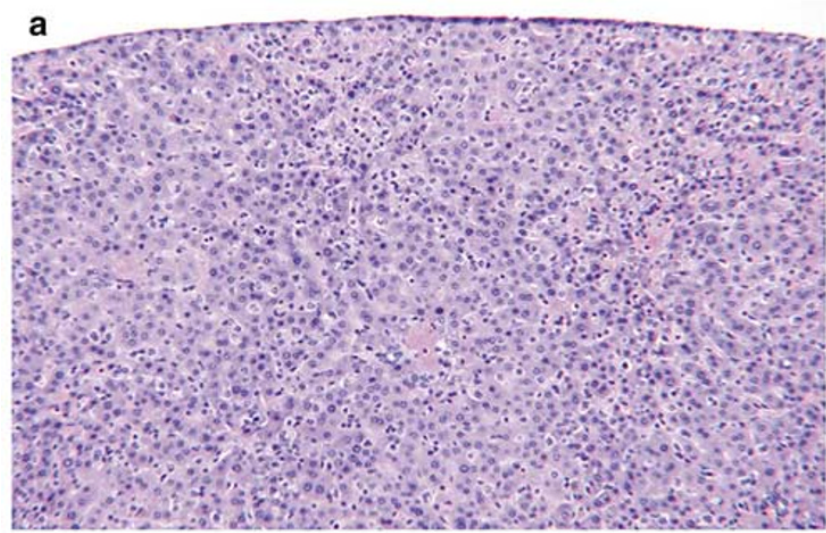

C

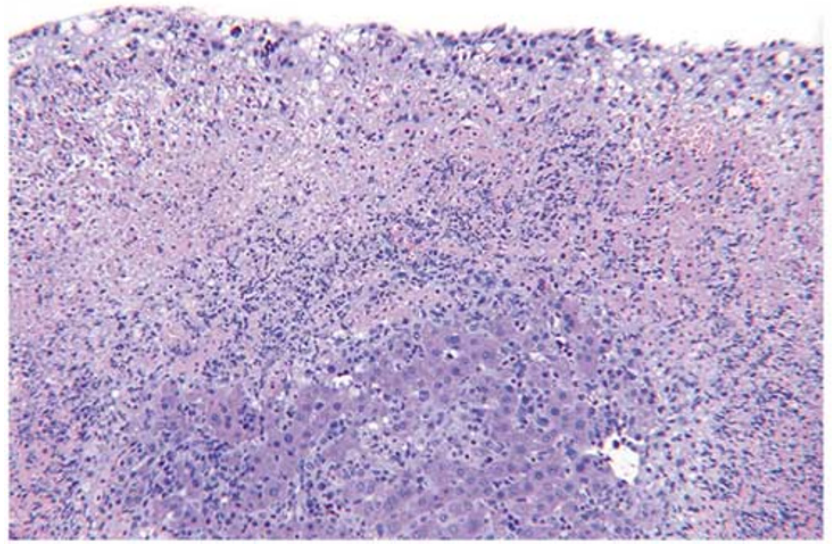

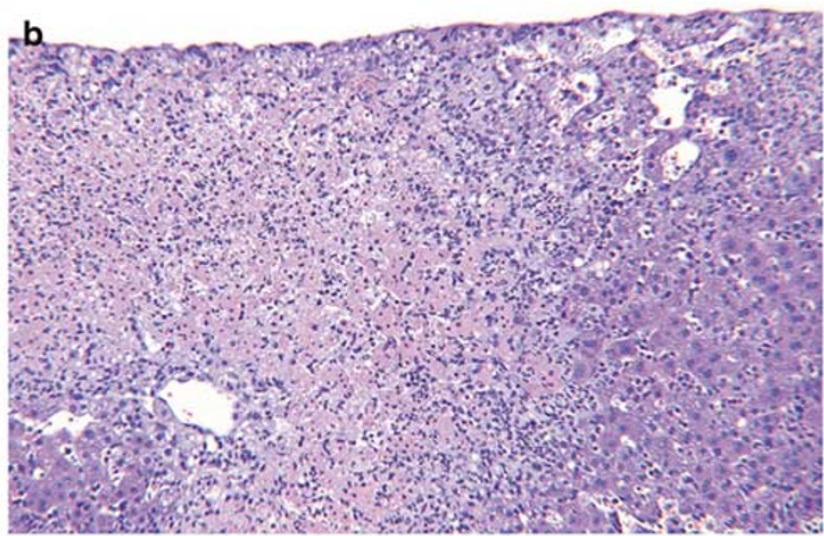

d

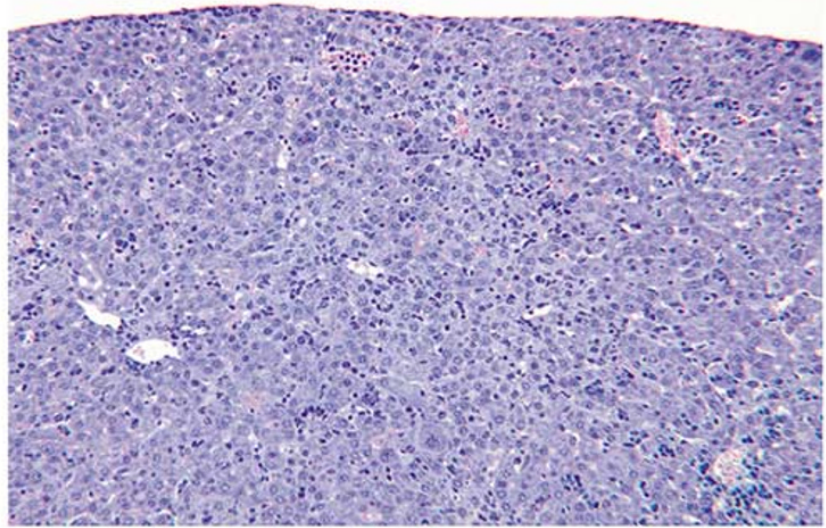

Figure 3 Liver histopathology in 129/CF-1 and BALB-background TGF- $\beta 1^{-1-}$ livers (H\&E-stained sections). (a) $129 / \mathrm{CF}-1$-TGF- $\beta 1^{-/-}$livers show no necroinflammatory liver disease; (b) BALB.B-TGF- $\beta 1^{-1-}$ and (c) BALB.K-TGF- $\beta 1^{-1-}$ livers exhibit necroinflammatory liver disease similar to that observed in BALB/C-TGF- $\beta 1^{-1-}$ livers; (d) F1(BALB/c $\times 129 / \mathrm{CF}-1$ )-TGF- $\beta 1^{-1-}$ livers show no necroinflammatory liver disease, indicating that the necroinflammatory liver disease phenotype is recessively inherited.

Table 2 Statistical analyses of plasma AST and ALT levels for H-2 congenic TGF- $\beta 1^{-1-}$ mice and littermate control mice

\begin{tabular}{|c|c|c|c|c|c|c|c|}
\hline \multirow[t]{2}{*}{ Strain, TGF- $\beta 1$ genotype } & \multirow[t]{2}{*}{ Analyte } & \multicolumn{6}{|c|}{ vs Strain, TGF- $\beta 1$ genotype } \\
\hline & & Littermate $^{\mathrm{a}}+/+$ & Littermate $^{\mathrm{a}}+/-$ & $B A L B / c-/-$ & $B A L B \cdot B-/-$ & $B A L B \cdot K-/-$ & $129 / C F-1-/-$ \\
\hline $\mathrm{BALB} / \mathrm{c}-/-$ & AST & $<0.0001^{\mathrm{b}}$ & $<0.0001$ & N/A & NS & NS & $<0.0001$ \\
\hline BALB.B -/- & AST & 0.0002 & $<0.0001$ & NS & N/A & NS & $<0.0001$ \\
\hline BALB.K -I- & AST & $<0.0001$ & $<0.0001$ & NS & NS & N/A & $<0.0001$ \\
\hline 129/CF-1 -/- & AST & NS & 0.03 & $<0.0001$ & $<0.0001$ & $<0.0001$ & N/A \\
\hline BALB/c - /- & ALT & $<0.0001$ & $<0.0001$ & N/A & NS & NS & $<0.0001$ \\
\hline BALB.B -/- & ALT & 0.0003 & 0.0008 & NS & N/A & NS & $<0.0001$ \\
\hline BALB.K -/- & ALT & 0.006 & $<0.0001$ & NS & NS & N/A & $<0.0001$ \\
\hline 129/CF-1 -/- & ALT & NS & 0.04 & $<0.0001$ & $<0.0001$ & $<0.0001$ & N/A \\
\hline
\end{tabular}

${ }^{\mathrm{a} C}$ Comparison is between TGF- $\beta 1$ knockout mice and either wild-type or heterozygous mice from within the same genetic background.

${ }^{\mathrm{b}}$ The numbers indicate the $P$-value calculated in group-group comparison using the Student's $t$-test.

NS: $P$-value not significant ( $>0.05$ ); N/A: not applicable.

were identified in any other organ examined, including the kidney (Figure 5d), bowel (Figure $5 \mathrm{e})$, and brain (Figure 5f). Also, our previous work $^{21,22}$ showed that liver pathology does not develop in BALB/C-TGF- $\beta 1^{-/-}$mice that also lack either all adaptive lymphocytes, only CD $4^{+} \mathrm{T}$ cells, or the Th1 cytokine IFN- $\gamma$, confirming that the etiology of the liver damage is Th1-mediated autoimmunity. The distinctive pathology and rapid kinetics associated with autoimmune liver disease in BALB/C-TGF- $\beta 1^{-/-}$mice underscore the significant differences in pathogenesis between this model 

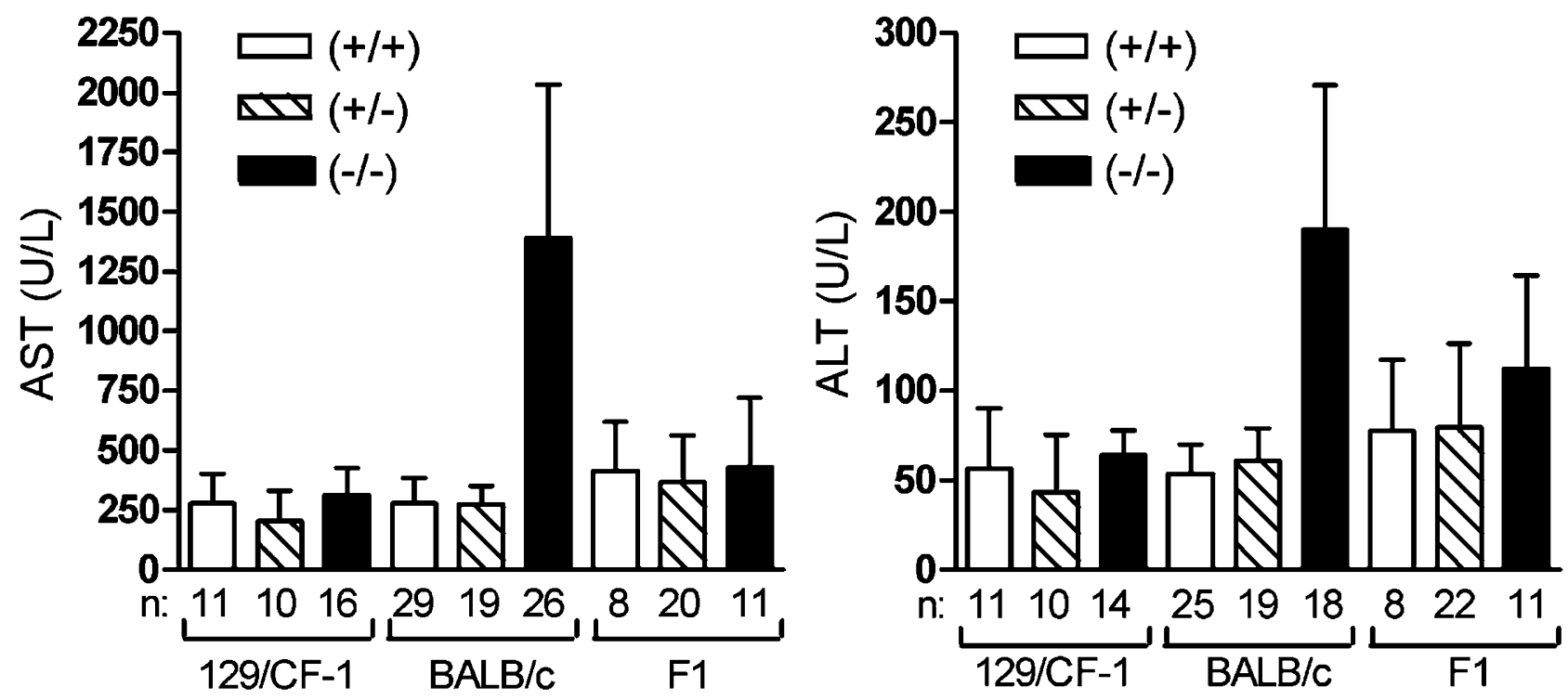

Figure 4 BALB-background necroinflammatory liver disease in TGF- $\beta 1^{-/-}$mice is recessively inherited. Litters from TGF- $\beta 1^{+/-}$ intercrosses on the genetic backgrounds shown were killed at postnatal day 11-12 and plasma samples were collected for AST and ALT analyses. Bars show means + SD for TGF- $\beta 1$ wild-type $(+/+)$ heterozygous $(+/-)$ and knockout $(-/-)$ mice, respectively, within each genetic background. The numbers $(n)$ of mice analyzed in each group are shown below the bars. Corresponding statistical analyses are shown in Table 3. F1: Intercross between 129/CF-1-TGF- $\beta 1^{+/-}$mice and BALB/c-TGF- $\beta 1^{+/-}$mice.

Table 3 Statistical analyses of plasma AST and ALT levels for F1-TGF- $\beta 1^{-1-}$ mice and littermate control mice

\begin{tabular}{|c|c|c|c|c|c|}
\hline \multirow[t]{2}{*}{ Strain, TGF- $\beta 1$ genotype } & \multirow[t]{2}{*}{ Analyte } & \multicolumn{4}{|c|}{ vs Strain, TGF- $\beta 1$ genotype } \\
\hline & & Littermate $^{\mathrm{a}}+/+$ & Littermate $^{\mathrm{a}}+/-$ & $129 / C F-1-/-$ & $B A L B / c-/-$ \\
\hline $\mathrm{F} 1-/-$ & AST & NS & NS & NS & $<0.0001^{\mathrm{b}}$ \\
\hline F1-/- & ALT & NS & NS & 0.003 & 0.008 \\
\hline
\end{tabular}

${ }^{\mathrm{a} C}$ Comparison is between F1-TGF- $\beta 1$ knockout mice and either wild-type or heterozygous F1 mice.

${ }^{\mathrm{b}}$ The numbers indicate the $P$-value calculated in group-group comparison using the Student's $t$-test.

NS: $P$-value not significant $(>0.05)$.

system and human AIH. While these differences limit the degree to which the current findings are directly applicable to human AIH, the current work demonstrates the existence, at least in mice, of genetic determinants distinct from the MHC that determine susceptibility to T-cell-mediated autoimmune hepatocellular injury.

\section{Discussion}

The BALB/c H-2 ${ }^{\mathrm{d}}$ haplotype is neither necessary nor sufficient for the development of necroinflammatory liver disease in BALB-background TGF- $\beta 1^{-1-}$ mice. This finding was unexpected for several reasons. First, in human AIH, MHC haplotype is an important genetic risk factor, and indeed, AIH is notable as one of the initial autoimmune diseases for which an MHC association was identified. ${ }^{4}$ Second, in several other murine organ-specific autoimmune disease models, MHC (H-2) haplotype plays an important and perhaps dominant role in genetic susceptibility. Third, necroinflammatory liver disease in BALB/c-TGF- $\beta 1^{-1-}$ mice is dependent upon $\mathrm{CD}^{+}{ }^{+} \mathrm{T}$ cells, and $\mathrm{H}-2$ haplotype is the key genetic restriction element molding the peripheral CD4 ${ }^{+}$T-cell receptor (TCR) repertoire.

For these reasons, we hypothesized that the BALB/C-specific $\mathrm{H}-2^{\mathrm{d}}$ haplotype is an important genetic risk factor for the development of necroinflammatory liver disease in TGF- $\beta 1^{-1-}$ mice. The availability of BALB-background mice congenic for other haplotypes at the H-2 locus (BALB.B and BALB.K) allowed us to test this hypothesis directly and rigorously. The data clearly disprove our hypothesis. That is, the development of necroinflammatory liver disease in BALB-background TGF$\beta 1^{-/-}$mice does not require the $\mathrm{H}-2^{\mathrm{d}}$ haplotype. Necroinflammatory liver disease developed with equal intensity in BALB-background TGF- $\beta 1^{-1-}$ mice bearing only d haplotypes, only b haplotypes, or only $\mathrm{k}$ haplotypes. Moreover, expression of the BALB/C H-2 ${ }^{\mathrm{d}}$ haplotype is insufficient for the development of necroinflammatory liver disease in 

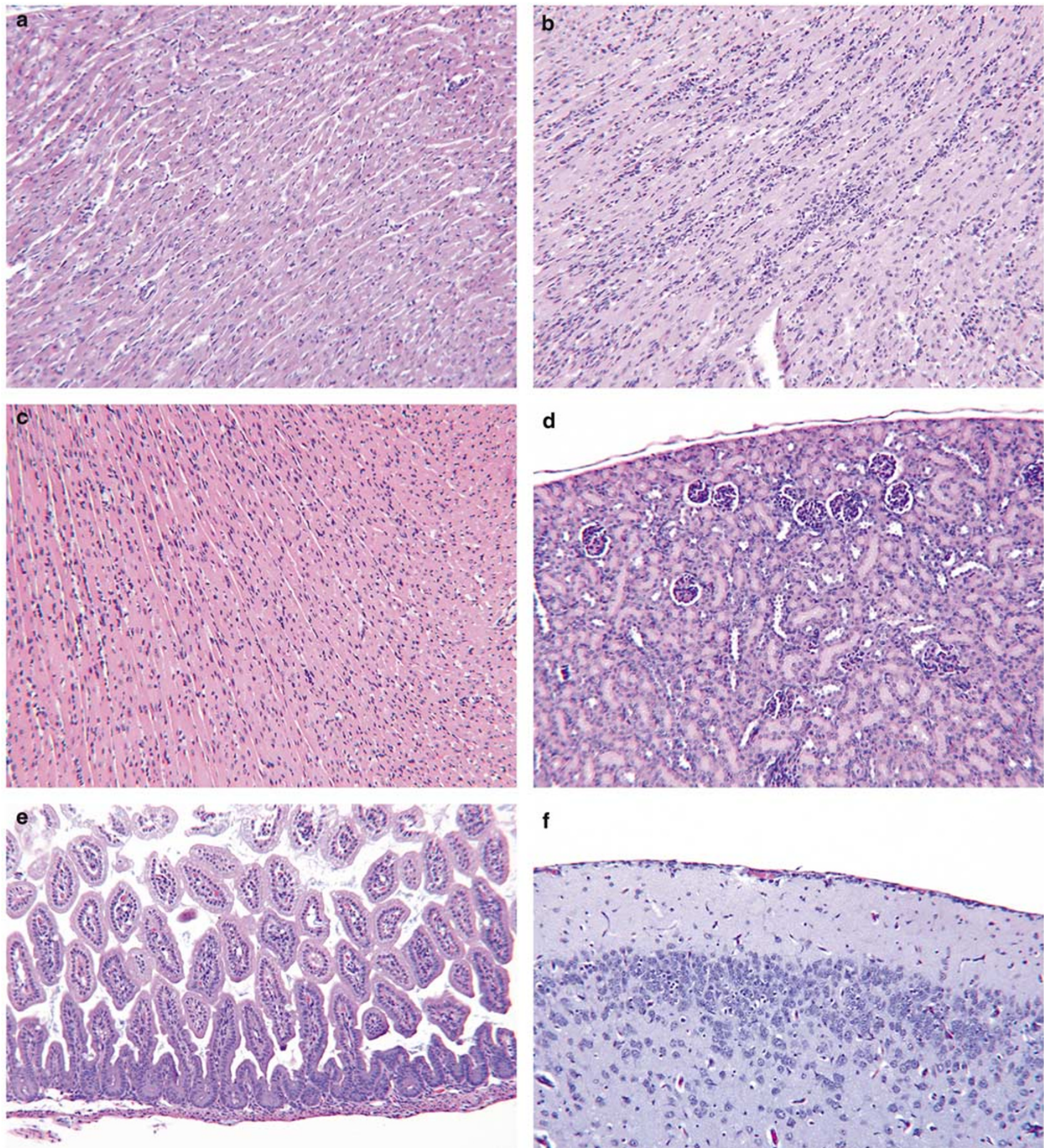

f

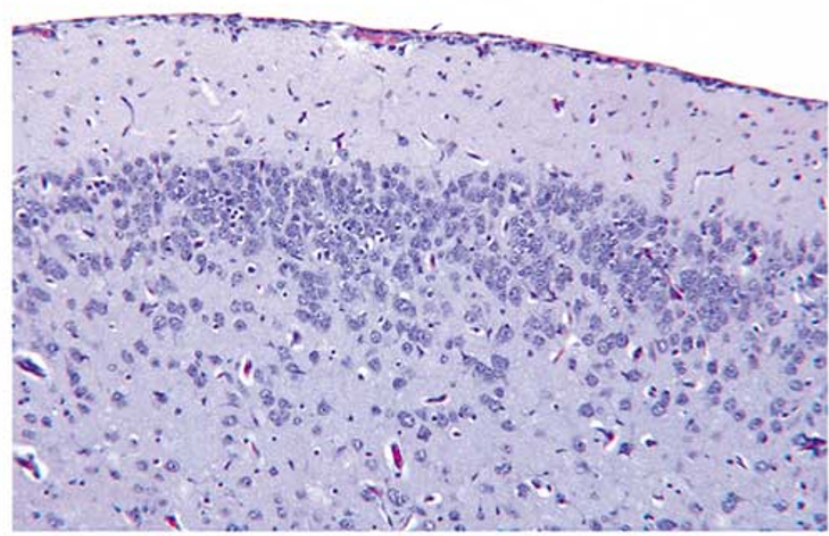

Figure 5 Histologic findings in other organs from BALB/c-TGF- $\beta 1^{-1-}$ mice (H\&E-stained sections). (a) Heart from BALB/c-TGF- $\beta 1^{+/+}$ control mouse; (b) myocarditis-like lymphocytic infiltration of the myocardium in a BALB/C-TGF- $\beta 1^{-/-}$heart; (c) heart from $129 / \mathrm{CF}-1$ TGF- $\beta 1^{-/-}$mouse without significant lymphocytic infiltration; (d) kidney, (e) small bowel, and (f) brain from BALB/c-TGF- $\beta 1^{-/-}$mice show no histopathological changes.

TGF- $\beta 1^{-1-}$ mice, as F1 (BALB/C $\left.\times 129 / \mathrm{CF}-1\right)$ TGF$\beta 1^{-/-}$mice, which harbor one $\mathrm{H}-2^{\mathrm{d}}$ haplotype, did not develop necroinflammatory liver disease. Thus, although necroinflammatory liver disease in $\mathrm{BALB} / \mathrm{c}-\mathrm{TGF}-\beta 1^{-/-}$mice is determined by genetic background and is dependent upon $\mathrm{CD} 4^{+} \mathrm{T}$ cells, it is not dependent upon the BALB/c-background MHC haplotype $\mathrm{H}-2^{\mathrm{d}}$ and develops with equal intensity in BALB-background mice bearing other MHC haplotypes (b or $\mathrm{k}$ ). These data strongly 
suggest that a locus or loci distinct from the mouse MHC locus $\mathrm{H}-2$ is/are the principal genetic determinants of necroinflammatory liver disease in this model of autoimmune hepatocellular injury.

Our preliminary assessment of the $\mathrm{H}$-2 haplotype(s) present in $129 / \mathrm{CF}-1-\mathrm{TGF}-\beta 1^{-/-}$mice is consistent with this conclusion. We tested the $\mathrm{H}-2$ haplotype of cells from four male and four female $129 / \mathrm{CF}-1$-TGF- $\beta 1^{+/-}$breeder mice in our colony using our available typing reagents, and all eight were reactive with anti-H-2 ${ }^{b}$ mAb, but none were reactive with anti-H- $-2^{\mathrm{d}} \mathrm{mAb}$ or anti- $\mathrm{H}-2^{\mathrm{k}} \mathrm{mAb}$ (TJK, unpublished). Therefore, it is likely that the $129 / \mathrm{CF}$ 1 -TGF- $\beta 1^{-1-}$ mice evaluated in the current study are uniformly $\mathrm{H}-2^{\mathrm{b} / \mathrm{b}}$ (or more precisely the closely related minor variant $\mathrm{H}-2^{\mathrm{bc} / \mathrm{bc}}$; see Materials and methods for more details). The development of necroinflammatory liver disease in $\mathrm{H}-2^{\mathrm{b} / \mathrm{b}}$ BALB.BTGF- $\beta 1^{-/-}$mice but not in $\mathrm{H}-2^{\mathrm{b} / \mathrm{b}} 129 / \mathrm{CF}-1$-TGF- $\beta 1^{-1-}$ mice is further evidence to support the conclusion that a genetic locus or loci unlinked to $\mathrm{H}-2$ regulate(s) the development of liver damage in TGF- $\beta 1^{-1-}$ mice.

These data permit the additional conclusion that the class II structural complex I-E is not a contributor to liver disease. There are two structural class II complexes in mouse, termed I-A, and I-E, each of which is a heterodimeric structure composed of an alpha chain and a beta chain. I-E is not expressed from the $\mathrm{H}-2^{\mathrm{b}}$ locus due to a mutation in the I-E $\alpha$ gene, ${ }^{33}$ but is expressed from the $\mathrm{H}-2^{\mathrm{d}}$ or $\mathrm{H}-2^{\mathrm{k}}$ loci. Therefore, since BALB.B-TGF- $\beta 1^{-1-}$ mice develop liver injury, we may conclude that the I-E complex is dispensable for the development of necroinflammatory liver disease in TGF- $\beta 1^{-/-}$mice. This implicates the I-A complex, and peptides presented on I-A, as responsible for the development of necroinflammatory disease in this CD4 ${ }^{+}$Tcell-dependent model of autoimmune hepatocellular injury. The repertoire of peptides presented by class II molecules has been difficult to establish owing to the size heterogeneity of class II peptides. While some studies using synthetic peptides indicate little specificity in the peptide repertoire bound by different alleles of class II MHC complexes, ${ }^{34,35}$ a recent study analyzing naturally processed peptides shows a high degree of specificity in peptide selection by I-A alleles. ${ }^{36}$ Allelic specificity in peptide selection may be a function of structural differences between residues found in the peptide binding pockets of the respective allelic I-A molecules. ${ }^{37,38}$ Identifying the target peptide(s) for hepatic $\mathrm{CD} 4^{+} \mathrm{T}$ cells in BALB-TGF- $\beta 1^{-/-}$livers remains an important goal, but such information will have to be reconciled with the implications of this study, that is, that I-A $\mathrm{A}^{\mathrm{d}}, \mathrm{I}-\mathrm{A}^{\mathrm{b}}$, and $\mathrm{I}-\mathrm{A}^{\mathrm{k}}$ are equally capable of supporting the development of necroinflammatory liver disease in BALB-background TGF- $\beta 1^{-/-}$mice.

How is autoimmune liver disease genetically regulated in TGF- $\beta 1^{-/-}$mice? The studies herein represent a candidate approach, designed to test the specific hypothesis that $\mathrm{H}-2^{\mathrm{d}}$ is a susceptibility haplotype. The results show that $\mathrm{H}-2^{\mathrm{d}}$ is not required, and strongly argue that the MHC is not an important regulatory locus for this model system, but rather that one or more non-MHC loci regulate $\mathrm{CD} 4{ }^{+}$-T-cell-dependent hepatocellular damage in TGF- $\beta 1^{-1-}$ mice. A comparison of several features of hepatic CD4 ${ }^{+} \mathrm{T}$ cells from BALB/C-TGF- $\beta 1^{-1-}$ mice with hepatic CD4 ${ }^{+}$T cells from 129/CF-1-TGF$\beta 1^{-/-}$mice reveals no obvious differences, either in numbers (from either genetic background, hepatic TGF- $\beta 1^{-\prime-} \mathrm{CD}^{+} \mathrm{T}$ cells are present at $3-10$-fold higher numbers compared with littermate controls; data not shown) activation status (by flow cytometry analysis, hepatic CD4 ${ }^{+}$T cells from TGF- $\beta 1^{-/-}$mice of either background are $\mathrm{CD} 44^{\mathrm{hi}} \mathrm{CD} 62 \mathrm{~L}^{\text {lo }}$; data not shown), or Th1 skewing (hepatic CD4 ${ }^{+} \mathrm{T}$ cells from TGF- $\beta 1^{-/-}$mice of either background produce copious IFN- $\gamma^{21}$ ). Thus, in both 129/CF-1-TGF- $\beta 1^{-1-}$ mice and BALB/c-TGF- $\beta 1^{-/-}$mice, livers are confronted with large numbers of activated Th1 cells. In the former, however, there is little to no hepatocellular damage, whereas in the latter, hepatocellular damage is extensive and widespread. We speculate that the relevant regulatory locus (or loci) may exert its/their effects not in the immune cell compartment, but rather in the hepatocellular compartment, for example by regulating the sensitivity of hepatocytes to apoptotic signals delivered by $\mathrm{T}$ cells or other effector cells, such as IFN- $\gamma$, TNF- $\alpha$, or Fas Ligand.

The etiology of the severe necroinflammatory liver disease observed in BALB/C-TGF- $\beta 1^{-/-}$mice is not entirely clear. The subcapsular and centrilobular pattern of hepatocellular necrosis associated with polymorphonuclear cells resembles that seen in ischemic hepatitis, a possibility made more plausible due to the presence of myocarditis-like lymphocytic inflammmatory infiltrates in the hearts of BALB/c-TGF- $\beta 1^{-/-}$mice. However, other evidence argues against global hypoperfusion as the sole cause for the hepatic pathology observed in this study, as ischemic-type necrosis was not found at necropsy in organs that are particularly susceptible to this type of injury, such as bowel, kidney, and brain. In addition, prior experiments performed by our group have demonstrated that intrahepatic $\mathrm{CD}^{+}$T cells from TGF- $\beta 1^{-1-}$ mice have increased cytolytic activity. ${ }^{22}$ Moreover, BALB/c-TGF- $\beta 1^{-1-}$ IFN- $\gamma^{-1-}$ double knockout mice do not exhibit hepatocellular necrosis despite the presence of myocardial lymphocytic infiltrates. ${ }^{21}$ These data suggest that the hepatocellular damage in TGF- $\beta 1^{-1-}$ mice is immune mediated, and not due to systemic ischemia. Indeed, BALB/C-TGF- $\beta 1^{-/-}$mice that are also deficient in all adaptive $B$ and $T$ cells or only the $\mathrm{CD}^{+}{ }^{+} \mathrm{T}$ lymphocyte subset do not develop hepatocellular injury, ${ }^{22}$ demonstrating that adaptive $\mathrm{CD}^{+}{ }^{+} \mathrm{T}$ lymphocytes play a critical role in mediating necroinflammatory liver disease. CD4 ${ }^{+} \mathrm{T}$ cells from BALB/C-TGF- $\beta 1^{-/-}$livers produce very high 
levels of both IFN- $\gamma$ and TNF- $\alpha$. Local high concentrations of these cytokines in liver may participate in hepatocellular damage. Recently, Schramm et $a l^{39}$ showed that TGF- $\beta 1$ acting directly on T cells is important for hepatoprotection, as transgenic mice expressing a dominant-negative TGF- $\beta$ receptor specifically in $\mathrm{T}$ cells were rendered much more susceptible to liver disease than control animals in a mouse model of inducible T-cell-mediated autoimmune hepatitis. Interestingly, $\mathrm{T}$ cells from these mice produced high levels of IFN- $\gamma$. Thus, TGF- $\beta 1$ may protect the liver indirectly, at least in part, by inhibiting Th1 differentiation, and subsequent intrahepatic production of IFN- $\gamma$ and other hepatotoxic substances by $\mathrm{T}$ cells.

In conclusion, the identification of allelic genetic loci other than MHC that regulate the development of autoimmune-mediated hepatocellular damage has been difficult heretofore, owing to the low prevalence of $\mathrm{AIH}$ and the reliance on candidate gene disease association studies. The development of the TGF- $\beta 1^{-1-}$ mouse model of autoimmune hepatocellular damage allows for the possibility of locating and identifying such loci through more efficient and robust genetic methods, such as the use of interspecific crosses and genomewide quantitative trait locus analyses, ${ }^{40}$ which are currently underway in our laboratory.

\section{Acknowledgements}

We thank Alice Givan for help with FACS analysis, and Christine Kretowicz and Beverly Gorham with help with mouse husbandry and screening. This project was supported by the following grants: a Research Scholar Award (JDG) from the Foundation for Digestive Health and Nutrition, National Institutes of Health Grant R01AI053056 (JDG), P20RR16437 from the COBRE Program of the National Center for Research Resources, and a Hitchcock Foundation Grant (JTL).

\section{References}

1 Krawitt EL. Autoimmune hepatitis. N Engl J Med 1996;334:897-903.

2 Lohr HF, Schlaak JF, Gerken G, et al. Phenotypical analysis and cytokine release of liver-infiltrating and peripheral blood $\mathrm{T}$ lymphocytes from patients with chronic hepatitis of different etiology. Liver 1994;14: 161-166.

3 Hussain MJ, Mustafa A, Gallati $\mathrm{H}$, et al. Cellular expression of tumour necrosis factor-alpha and interferon-gamma in the liver biopsies of children with chronic liver disease. J Hepatol 1994;21:816-821.

4 Mackay IR, Morris PJ. Association of autoimmune active chronic hepatitis with HL-A1,8. Lancet 1972; 2:793-795.
5 Lindberg J, Lindholm A, Iwarson S. Genetic factors in the development of chronic active hepatitis. Lancet 1977;1:67-68.

6 Page AR, Sharp HL, Greenberg LJ, et al. Genetic analysis of patients with chronic active hepatitis. J Clin Invest 1975;56:530-535.

7 Donaldson PT, Doherty DG, Hayllar KM, et al. Susceptibility to autoimmune chronic active hepatitis: human leukocyte antigens DR4 and A1-B8-DR3 are independent risk factors. Hepatology 1991;13: 701-706.

8 Mackay IR, Tait BD. HLA associations with autoimmune-type chronic active hepatitis: identification of B8-DRw3 haplotype by family studies. Gastroenterology 1980;79:95-98.

9 Seki T, Ota M, Furuta S, et al. HLA class II molecules and autoimmune hepatitis susceptibility in Japanese patients. Gastroenterology 1992;103:1041-1047.

10 Williams RM, Martin S, Falchuk KR, et al. Increased frequency of HLA-DRW4 in chronic active hepatitis. Vox Sang 1978;35:366-369.

11 Czaja AJ, Donaldson PT. Genetic susceptibilities for immune expression and liver cell injury in autoimmune hepatitis. Immunol Rev 2000;174:250-259.

12 Donaldson PT. Genetics in autoimmune hepatitis. Semin Liver Dis 2002;22:353-364.

13 Donaldson PT, Czaja AJ. Genetic effects on susceptibility, clinical expression, and treatment outcome of type 1 autoimmune hepatitis. Clin Liver Dis 2002; 6:419-437.

14 Agarwal K, Czaja AJ, Jones DE, et al. Cytotoxic T lymphocyte antigen-4 (CTLA-4) gene polymorphisms and susceptibility to type 1 autoimmune hepatitis. Hepatology 2000;31:49-53.

15 Cookson S, Constantini PK, Clare M, et al. Frequency and nature of cytokine gene polymorphisms in type 1 autoimmune hepatitis. Hepatology 1999;30:851-856.

16 Czaja AJ, Cookson S, Constantini PK, et al. Cytokine polymorphisms associated with clinical features and treatment outcome in type 1 autoimmune hepatitis. Gastroenterology 1999;117:645-652.

17 Wicker LS, Appel MC, Dotta F, et al. Autoimmune syndromes in major histocompatibility complex (MHC) congenic strains of nonobese diabetic (NOD) mice. The NOD MHC is dominant for insulitis and cyclophosphamide-induced diabetes. J Exp Med 1992; 176:67-77.

18 Todd JA, Aitman TJ, Cornall RJ, et al. Genetic analysis of autoimmune type 1 diabetes mellitus in mice. Nature 1991;351:542-547.

19 Encinas JA, Kuchroo VK. Mapping and identification of autoimmunity genes. Curr Opin Immunol 2000; 12:691-697.

20 Kono DH, Theofilopoulos AN. Genetics of systemic autoimmunity in mouse models of lupus. Int Rev Immunol 2000;19:367-387.

21 Gorham JD, Lin JT, Sung JL, et al. Genetic regulation of autoimmune disease: BALB/c background TGF-beta 1-deficient mice develop necroinflammatory IFNgamma-dependent hepatitis. J Immunol 2001;166: 6413-6422.

22 Rudner LA, Lin JT, Park IK, et al. Necroinflammatory liver disease in BALB/c background, TGF-beta1-deficient mice requires $\mathrm{CD} 4(+) \mathrm{T}$ cells. J Immunol 2003;170:4785-4792.

23 Shull MM, Ormsby I, Kier AB, et al. Targeted disruption of the mouse transforming growth factor- 
beta 1 gene results in multifocal inflammatory disease. Nature 1992;359:693-699.

24 Darvasi A, Soller M. Advanced intercross lines, an experimental population for fine genetic mapping. Genetics 1995;141:1199-1207.

25 Fischer LK. On naming $\mathrm{H} 2$ haplotypes: functional significance of MHC class Ib alleles. Immunogenetics 1997;46:53-62.

26 Snell GD, Graff RJ, Cherry M. Histocompatibility genes of mice. XI. Evidence establishing a new histocompatibility locus, H-12, and new H-2 allele, H-2bc. Transplantation 1971;11:525-530.

27 Houlden BA, Matis LA, Cron RQ, et al. A TCR gamma delta cell recognizing a novel TL-encoded gene product. Cold Spring Harb Symp Quant Biol 1989; $54: 45-55$

28 Melvold RW, Wang K, Kohn HI. Histocompatibility gene mutation rates in the mouse: a 25-year review. Immunogenetics 1997;47:44-54.

29 Dickson MC, Martin JS, Cousins FM, et al. Defective haematopoiesis and vasculogenesis in transforming growth factor-beta 1 knock out mice. Development 1995;121:1845-1854.

30 Kallapur S, Ormsby I, Doetschman T. Strain dependency of TGFbeta1 function during embryogenesis. Mol Reprod Dev 1999;52:341-349.

31 Boivin GP, O'Toole BA, Orsmby IE, et al. Onset and progression of pathological lesions in transforming growth factor-beta 1-deficient mice. Am J Pathol 1995;146:276-288.

32 Kulkarni AB, Ward JM, Yaswen L, et al. Transforming growth factor-beta 1 null mice. An animal model for inflammatory disorders. Am J Pathol 1995;146: 264-275.
33 Mathis DJ, Benoist C, Williams VE, et al. Several mechanisms can account for defective $\mathrm{E}$ alpha gene expression in different mouse haplotypes. Proc Natl Acad Sci USA 1983;80:273-277.

34 Sidney J, del Guercio MF, Southwood S, et al. The HLA molecules DQA1*0501/B1*0201 and DQA1*0301/B1*0302 share an extensive overlap in peptide binding specificity. J Immunol 2002;169: 5098-5108.

35 Southwood S, Sidney J, Kondo A, et al. Several common HLA-DR types share largely overlapping peptide binding repertoires. J Immunol 1998;160: 3363-3373.

36 Suri A, Walters JJ, Kanagawa O, et al. Specificity of peptide selection by antigen-presenting cells homozygous or heterozygous for expression of class II MHC molecules: The lack of competition. Proc Natl Acad Sci USA 2003;100:5330-5335.

37 Suri A, Vidavsky I, van der Drift K, et al. In APCs, the autologous peptides selected by the diabetogenic I-Ag7 molecule are unique and determined by the amino acid changes in the P9 pocket. J Immunol 2002; 168:1235-1243.

38 Nelson CA, Viner NJ, Young SP, et al. A negatively charged anchor residue promotes high affinity binding to the MHC class II molecule I-Ak. J Immunol 1996; 157:755-762.

39 Schramm C, Protschka M, Kohler HH, et al. Impairment of TGF-beta signaling in $\mathrm{T}$ cells increases susceptibility to experimental autoimmune hepatitis in mice. Am J Physiol Gastrointest Liver Physiol 2003;284:G525-G535.

40 Cox RD, Brown SD. Rodent models of genetic disease. Curr Opin Genet Dev 2003;13:278-283. 